\title{
The pathogenesis of COPD and IPF: Distinct horns of the same devil?
}

\author{
Marco Chilosi ${ }^{1 *}$, Venerino Poletti ${ }^{2}$ and Andrea Rossi ${ }^{3}$
}

\begin{abstract}
New paradigms have been recently proposed in the pathogenesis of both chronic obstructive pulmonary disease (COPD) and idiopathic pulmonary fibrosis (IPF), evidencing surprising similarities between these deadly diseases, despite their obvious clinical, radiological and pathologic differences. There is growing evidence supporting a "double hit" pathogenic model where in both COPD and IPF the cumulative action of an accelerated senescence of pulmonary parenchyma (determined by either telomere dysfunction and/or a variety of genetic predisposing factors), and the noxious activity of cigarette smoke-induced oxidative damage are able to severely compromise the regenerative potential of two pulmonary precursor cell compartments (alveolar epithelial precursors in IPF, mesenchymal precursor cells in COPD/emphysema). The consequent divergent derangement of signalling pathways involved in lung tissue renewal (mainly Wht and Notch), can eventually lead to the distinct abnormal tissue remodelling and functional impairment that characterise the alveolar parenchyma in these diseases (irreversible fibrosis and bronchiolar honeycombing in IPF, emphysema and airway chronic inflammation in COPD).
\end{abstract}

Keywords: COPD, IPF, precursor cell senescence, telomere dysfunction, Wnt, Notch, Caveolin-1

\section{Introduction}

Chronic obstructive pulmonary disease (COPD) and idiopathic pulmonary fibrosis (IPF) are two severe multifactorial pulmonary disorders characterised by quite distinct clinical and pathological features. COPD is characterised by a poorly reversible and progressive airflow limitation that is determined by the concurrence of airways inflammation and emphysema (from now on both included in the acronym COPD) [1,2], whereas in IPF a restrictive pattern of lung volume abnormality is associated with impaired diffusion capacity [3]. At imaging and pathological examinations COPD and IPF exhibit different appearances, as far as the involved pulmonary regions (upper lobes versus lower lobes), and the occurring parenchymal modifications are concerned (alveolar emphysematous dilation and bronchiolar inflammation in COPD, versus interstitial fibrosis and honeycombing in IPF)[1-3]. Finally, the incidence and prevalence of the two diseases are quite different, since IPF is considered a rare condition (although incidence and prevalence are both rising due to improved

\footnotetext{
* Correspondence: marco.chilosi@univr.it

${ }^{1}$ Department of Pathology, University of Verona, Italy

Full list of author information is available at the end of the article
}

diagnostic tools), whereas the COPD prevalence is very high, although variable in different risk populations $[4,5]$.

Nevertheless, a number of similarities can be recognised between the two disorders. Firstly, both COPD and IPF are chronic and progressive diseases of elderly people (with male predominance), that severely affect the lung function, and both are related to long term inhalation of external noxious agents (mainly tobacco smoking) $[3,4,6,7]$. Secondly, in both diseases a progressive loss of alveolar parenchyma takes place leading to severe impairment of respiratory function. Variants of pulmonary fibrosis associated with emphysema have been described, and these cases have been grouped in a newly defined syndrome of combined pulmonary fibrosis and emphysema (CPFE)[8]. In CPFE, lung volumes are commonly within normal limits due to the opposing effects of hyperinflation and fibrosis. The CPFE syndrome is more frequent in male smokers, and pulmonary hypertension can complicate all these disorders $[8,9]$. Finally, both IPF and COPD are associated with an increased risk of cancer development, and several lines of evidence suggest that this increase is independent from the effect of cigarette smoking $[10,11]$.
C Biomed Central

() 2012 Chilosi et al; licensee BioMed Central Ltd. This is an Open Access article distributed under the terms of the Creative Commons Attribution License (http://creativecommons.org/licenses/by/2.0), which permits unrestricted use, distribution, and reproduction in any medium, provided the original work is properly cited. 
Despite the great deal of research, effective treatments are lacking for both COPD and IPF. This can be a consequence, at least in part, of the limited understanding of their pathogenesis, despite the overwhelming plethora of studies and theories proposed so far. Interestingly, for both diseases a gradual shift from "inflammatory-based" pathogenic theories to more complex approaches occurred in recent years $[12,13]$. In this evolving scenario, a variety of concurrent underlying pathogenic mechanisms have been proposed for these diseases, including oxidative stress, protease/anti-protease imbalance, abnormal healing after damage, deranged remodelling, enhanced apoptosis, and others [14-18].

\section{Accelerated senescence in the pathogenesis of IPF and COPD}

The most striking new information linking the pathogenesis of IPF and COPD relates to their proposed inclusion within the category of diseases with alveolar senescence and lung "premature aging" [19-33]. The senescence hypothesis for both COPD and IPF pathogenesis is supported by a variety of studies demonstrating telomere length abnormalities, as well as the in situ expression of senescence-related cell-cycle regulators (p21 ${ }^{\text {WAF1 }}$ and $\left.\mathrm{p} 16^{\mathrm{INK} 4 \mathrm{a}}\right)[19,25,34,35]$. The role of cell senescence is particularly evident in familial IPF, where nearly $10 \%$ of cases harbour mutations of one of the two key components involved in telomere lengthening: the reverse transcriptase component TERT and the RNA template component TERC $[29,30]$. In addition, about $20 \%$ of patients suffering for dyskeratosis congenita, a well characterized genetic disease caused by telomerase mutations, develop pulmonary fibrosis [36].

Although abnormalities directly affecting telomerase genes have not been demonstrated in COPD, telomere decreased length has been demonstrated in either lung cells or peripheral leukocytes in COPD patients, compared with control subjects [21,24-27]. The excess of telomere attrition further supports the concept of COPD as a systemic disorder of premature aging, as also suggested by the occurrence of relevant comorbidities, such as weight loss, osteoporosis, cardiovascular diseases, and depression, where premature senescence and telomere length abnormalities have been also documented [37-39]. Further experimental evidence has been recently provided that telomere length is a susceptibility factor in emphysema [40].

\section{Epithelial progenitor cell dysfunction in IPF}

The pathogenic role of genetic abnormalities in IPF is much more evident than in COPD, and familial IPF has been recently included within the category of genetic diseases with "telomere dysfunction" together with acquired aplastic anaemia and dyskeratosis congenita
[41-44]. These diseases are characterised by clinical and pathologic heterogeneity despite the similarity of underlying genetic defects affecting the telomere elongating mechanisms (mainly TERT or TERC mutations). In these diseases specific phenotypes are likely related to the progenitor cell type(s) involved as "weak spots" in disease development (e.g. haemopoietic precursors in aplastic anaemia)[45]. A correct telomere maintaining program in precursor cells is crucial to avoid degenerative disorders and anticipated aging, and short telomeres cause precursor cell failure in experimental systems $[46,47]$. In addition, it has been clearly established that the development of diseases with "telomere dysfunction" needs the contribution of both a genetic predisposing abnormality as well as an environmental factor in order to develop the entire disease phenotype [45]. Thus, the exposure to benzene or other toxic substances, is key for the development of aplastic anaemia, as it can be considered tobacco smoke (or exposure to other toxic substances) in IPF. A significant role might be also exerted by gender [48], as it could be also expected in cases of pulmonary fibrosis complicating X-linked dyskeratosis congenita [49]. Accordingly, most described cases of pulmonary fibrosis complicating dyskeratosis congenita are former-smoker and male $[36,49,50]$.

Familial IPF cases have been linked not only to mutations of telomerase genes, but also to mutations in surfactant proteins coding genes (surfactant protein-C and A2)[51-54]. Chronic epithelial injury in these cases is likely related to protein abnormalities that can either impair the crucial functions of the surfactant, or induce endoplasmic reticulum stress and apoptosis [55]. TypeII pneumocytes, that are the main producers of surfactant proteins and are the epithelial precursors of alveolar parenchyma, are the specific target of cellular death produced by surfactant protein abnormalities.

Thus different mechanisms can be responsible of the progressive loss of pneumocyte precursors in IPF, including accelerated senescence, surfactant abnormalities and endoplasmic reticulum stress, all potentially causing precursor cell exhaustion and abnormal alveolar re-epithelialisation [56-59]. The concurrent action of environmental factors such as the exposure to toxic substances, and especially tobacco smoking and/or pollution appear as necessary for developing the disease in both familial and sporadic IPF, although IPF can occur also in non smokers $[6,60]$ (Figure 1).

\section{Mesenchymal precursor cell insufficiency in COPD/ emphysema}

In COPD a large amount of data suggest that parenchymal remodelling and progressive dilation of alveolar spaces is related to decreased and/or deregulated production of extracellular matrix proteins, in particular 


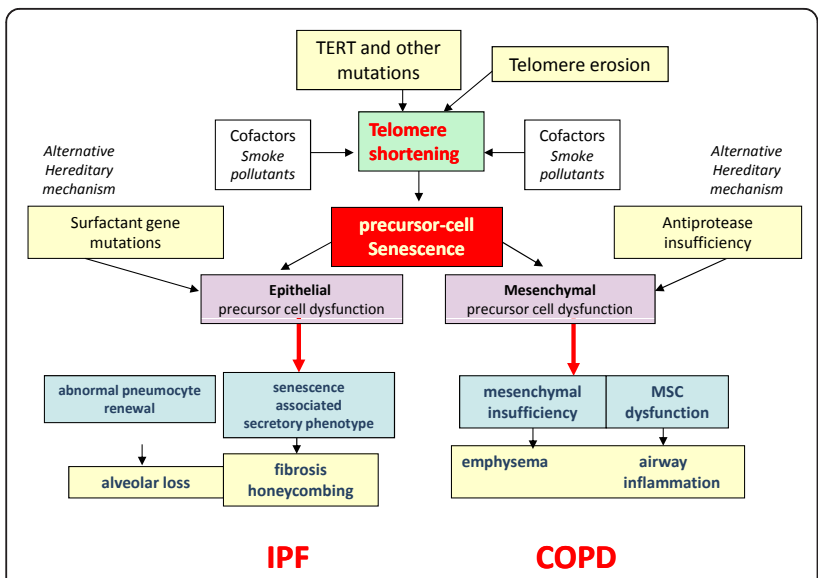

Figure 1 Pathogenic scheme of IPF and COPD. Summation of genetic and environmental factors underlay the abnormal renewal of either epithelial (left) or mesenchymal (right) alveolar components leading to parenchymal fibrotic obliteration and remodeling in IPF, or emphysematous changes and airway inflammation in COPD. The genetic background can be either hereditary (fully consistent with a "telomere dysfunction" as observed in familial IPF), or can variably provide a genetic susceptibility.

elastin, with the eventual impaired capability to sustain connective and epithelial tissue repair. Connective tissue insufficiency can be either caused by genetic defects as observed in alpha-1 anti-trypsin deficiency (a well established genetically determined form of COPD/emphysema where elastin decrease can be directly related to the observed alveolar dilation, loss of elastic recoil and airflow obstruction), or it may be ascribed to ill defined causes inducing mesenchymal precursor cell senescence and progressive decrease of matrix protein production, as suggested in this review. Accordingly, senescence related markers in COPD are mainly demonstrable in mesenchymal cells (fibroblasts and endothelial cells) [61], and a variety of abnormalities have been described affecting pulmonary mesenchymal cells, including fibroblasts and endothelial cells in both human and experimental COPD [62-68](Figure 1).

\section{IPF and COPD: two distinct horns of the same devil?}

All this taken into account, it is possible to hypothesise that in the pathogenesis of both COPD and IPF the main driving abnormality is the precocious senescence of pulmonary parenchyma.

But how can be reconciled this proposed similarity between the basic pathogenic mechanisms underlying COPD and IPF with the obvious diversity of their clinical and pathological presentations? A possible explanation can be searched in the diversity of the genetic alterations, including genetic/epigenetic inheritance or predisposing gene polymorphisms, compromising the renewal capacity of different target cells [69-71]. As proposed above, if in IPF the major target is likely the alveolar epithelial precursor cell (type II pneumocyte), in COPD the Achille's heel may be represented by mesenchymal precursor cells within the alveolar parenchyma.

Human and experimental studies provide strong evidence that molecular networks regulating parenchymal lung tissue renewal are perturbed in both COPD and IPF, although in different ways. Among these networks, particular relevance has been focused on the interplay between Notch and Wnt, two signalling pathways playing critical roles in epithelial and mesenchymal precursor cell maintenance and differentiation [72-78].

\section{Wnt and Notch pathway perturbation in IPF}

In IPF the senescent phenotype seems to mainly affect the epithelial precursors of alveolar tissue (type-II pneumocytes), thus preventing a correct epithelial renewal at anatomical sites where mechanical stress and alveolar damage are expected to be maximal (lower/peripheral lung zones) $[56,79]$. Pneumocyte loss is followed, in this pathogenic scheme of IPF, by attempted tissue regeneration and exaggerated release of molecular signals (Wnt and Notch) triggering fibroblast proliferation and migration. Several human and experimental studies have confirmed that the Wnt-pathway is abnormally activated in IPF, and this notion is included in recent pathogenic models for IPF $[17,56,80-82]$. The relevance of abnormal Wnt-signalling activation in IPF is confirmed by the upmodulation of various Wnt-pathway molecular targets observed in IPF (MMP7, cyclin-D1 and others) [80], as well as by the demonstration that experimental fibrosis can be attenuated by the Wnt/ $\beta$-catenin pathway blockade [83]. Accordingly, perturbation of the Wnt-pathway is directly related to abnormal myofibroblast activation and epithelial-mesenchymal transition [84], and mesenchymal precursor cells can further amplify the fibrotic process by triggering the Wnt-pathway [85]. Myofibroblasts are key elements in IPF and their differentiation can be also triggered by loss of telomerase activity [86]. Concurrently, Notch-signalling is crucial for myofibroblast differentiation and alveologenesis, and can also contribute to the differentiation of airway basal precursor cells [87].

But how can senescent pneumocytes abnormally trigger these pathways in IPF? Signals provided by the milieu of damaged alveolar cells can trigger a variety of reparative mechanisms, including the recruitment and stimulation of endogenous and exogenous progenitors [88], and it is possible to expect a severe derangement of this process in senescent alveoli. In several systems it has been demonstrated that cell senescence can trigger a "senescence-associated secretory phenotype", that is 
able to stimulate the production of proliferative and profibrotic mediators, including growth factors, cytokines, chemokines, and metalloproteinases [89], acting on neighbouring epithelial and mesenchymal cells thus perturbing their physiological crosstalk as previously proposed [16,17]. In line with this assumption, both Wnt- and Notch pathways have been shown to be activated by cell senescence, and epithelial mesenchymal transition and mobilization of beta-catenin are among the features characterising the senescence-related hypersecretive phenotype [88-95]. In senescent alveoli mesenchymal and epithelial precursors could be the target of this deranged cascade of stimulatory signals, with eventual myofibroblast activation and bronchiolar remodelling. Senescent myofibroblasts in turn could be also stimulated to acquire a secretive phenotype, and this effect is likely to occur at short distance from damaged areas, thus contributing to produce the patchy distortion of pulmonary tissue characterising the "usual interstitial pneumonia" (UIP) pattern. Recently, we demonstrated that fibroblast foci are mainly located within micro-honeycombing lesions in IPF, at sites where basal cell airway precursors abnormally show over-expression of molecules involved in cell-motility (laminin-5 $\gamma$-2-chain and heath shock protein 27), and molecules that can be directly related to cellular senescence including p $21^{\text {waf1 }}$ and p53 [96,97]. Small airways and alveolar epithelia are characterised by quite different renewal strategies at the molecular level, and telomere dysfunction and cellular senescence could be expected to act differently in these two compartments. Bronchiolar progenitors, located in the basal layer [98], express high levels of $\Delta \mathrm{N}-\mathrm{p} 63+$, a potent anti-apoptotic mediator that can interfere with the $\mathrm{p} 53 / \mathrm{p} 21$ pathway and may potentially contrast cell senescence in basal cells $[96,99]$. Bronchiolar abnormal proliferation and honeycomb changes are common in IPF and can be considered as consequence of divergent behaviours in proximal and distal lung compartments $[15,56,99]$. In our view, exaggerated autocrine and paracrine activation of the Wnt- and Notch-pathways can in part explain honeycomb cyst formation, since proliferation and differentiation of basal cell precursors in small airways depend on the correct expression of these signalling pathways [98]. Further contribute to the aberrant bronchiolar proliferation and honeycomb cyst formation in IPF is likely provided by abnormalities affecting the production of airway mucins, as recently demonstrated $[70,100]$. Interestingly, disordered mucin production with increased MUC5B forms is also observed in the airway of COPD patients [101].

\section{Wnt and Notch signalling perturbation in COPD}

Interestingly, the same signalling pathways involved in IPF (Wnt- and Notch), seem to have a relevant role also in COPD, but in the opposite way. In fact, both Wntand Notch- appear as significantly inhibited in COPD, rather than activated as observed in IPF [80-82,102,103], and this observation can explain why in emphysema enlarged alveoli are mainly covered by type-I differentiated pneumocytes and type II pneumocyte proliferation is minimal. In different systems in fact, the classical role of the Notch- and Wnt-signalling, acting in concert, is the maintenance of self-renewal potential of epithelial precursor cells and the regulation of cell differentiation [72-78], and the abnormal decrease of these pathways, as observed in emphysema, can be detrimental for the correct renewal of pulmonary parenchyma $[102,103]$. Accordingly, activation of the Wnt/beta-catenin pathway can attenuate experimental emphysema [104], and accelerated precursor cell senescence and dysfunction are related to aberrant Notch and Wnt-signalling, particularly affecting the correct differentiation of mesenchymal precursors [90-92].

The observed inhibition of Wnt-signalling in COPD may be ascribed to a variety of concurrent causes, including the smoking-related up-regulation of extracellular Wnt antagonists (e.g. secreted frizzled-related proteins) [103]. Interestingly, the Wnt-pathway is sensitive to mechanical stimuli in different systems, and it is considered to represent a key factor in mechano-transcription processes [105-108]. It is then possible to hypothesise that the decrease of elastic recoil occurring in emphysematous parenchyma may significantly contribute, in a vicious circle, to perpetuate the Wnt-signalling down-modulation. In IPF, on the other hand, Wnt activation could be amplified at sites where mechanical stress is higher (e.g. in the subpleural lower lung portions, typically affected in IPF), thus contributing to ongoing alveolar loss and fibrosis, as recently hypothesised [79].

All these data taken together, it is possible to hypothesise that in COPD the abnormal senescence of mesenchymal precursors can cause both an impaired production of extracellular matrix proteins (e.g. elastin), as well as a derangement of the interplay between signalling pathways that regulate alveologenesis (in particular Wnt and Notch). These abnormalities are likely sufficient to cause the progressive weakening of the scaffold interstitial structures sustaining the pulmonary parenchyma, with eventual alveolar dilatation and emphysema.

\section{Precursor cell senescence and inflammation in COPD- emphysema}

Interestingly, the here proposed pathogenic scheme, centred on alveolar senescence and mesenchymal precursor cell insufficiency, can in part reconcile some controversial issues regarding the significance and role of inflammation and autoimmunity in the development of 
airway disease occurring in COPD [2,20,109-115]. Evidence has been in fact provided of a robust regulatory function of mesenchymal stem cells (MSC) on cells of both the innate and adaptive immune systems, and bone marrow derived MSC are able to inhibit the release of pro-inflammatory cytokines and also stimulate the functional activity of regulatory T-lymphocytes [116-119]. The regulatory functions of MSC is similar in different tissues [120,121], including the lung [Ricciardi $M$, et al: unpublished data]. It is then possible to hypothesise that in COPD the regulatory functions of senescent MSC can be variably impaired, with eventual triggering of "autoimmune-like" chronic inflammation in small airways, similar to that observed in the variety of lung diseases presenting as constrictive bronchiolitis in different settings (lung allografts, exposure to toxic substances, autoimmunity, post-viral, etc.) [122-126]. According to this hypothesis is the recent demonstration of a direct role of mesenchymal cell senescence and telomere dysfunction in causing airway inflammation in COPD [127]. In this scheme, the airway remodelling characterising COPD could be tentatively explained by the concurrence action of the inflammatory stimuli derived by the above described inhibition of MSC immune-modulatory role, and the proliferative response of airway epithelium to the chronic damaging effect of exogenous toxic substances (e.g. cigarette smoke).

\section{Conclusions}

In summary, in both COPD and IPF a common pathogenic scheme can be traced where an accelerated cellular senescence determined by the "two hits" paradigm (genetic predisposition to cell senescence with the concurrence of tobacco smoke), determines an impaired regeneration of the lung parenchyma after damage. The divergence in two horns in this model is provided by the affected precursor cells (mesenchymal in COPD and emphysema, epithelial in IPF), the relevance of genetic background, as well as by the basic signalling pathways involved in the development of either emphysema or fibrosis (Wnt-, Notch-, etc.)(Figure 2). Both mechanisms could be involved in the cases with combined pulmonary fibrosis and emphysema $[8,9]$.

The complexity of this network is difficult to be completely deciphered in both IPF and COPD, since beyond precursor cell senescence, as here described, other genetic predisposing factors and molecular mechanisms are likely involved in both diseases, including microRNA regulation [128-133]. Interestingly, perturbation of micro-RNAs can also affect TGF-beta, a potent profibrotic effector, that plays a relevant role in early lung development, has significant interconnections with the Wnt-pathway, and is involved in the pathogenesis of both IPF and COPD [129,133-136]. Another player in this complex scenario is likely represented by caveolin-1,

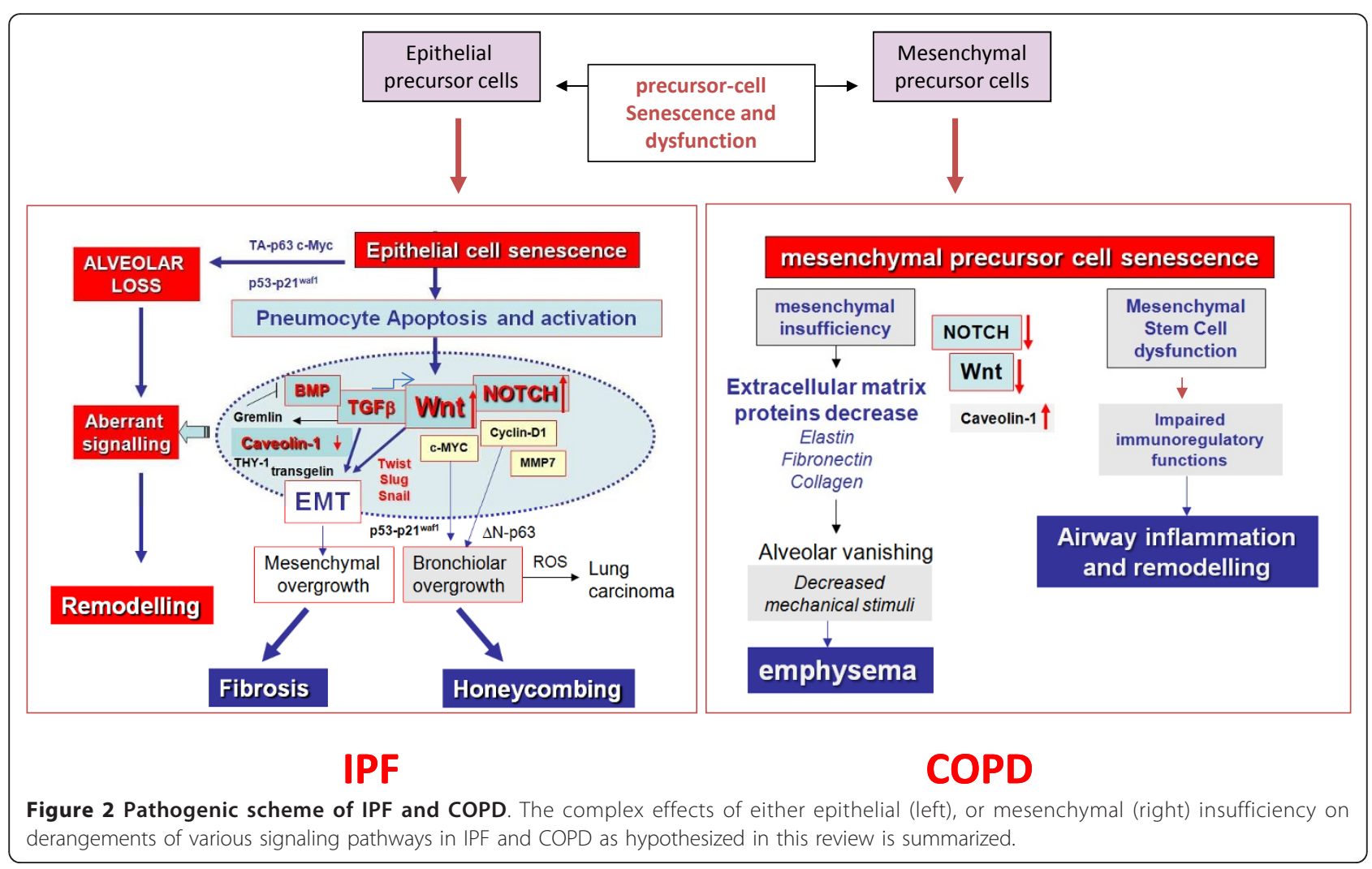


the member of a protein family involved in the formation of cellular caveolae, that plays divergent roles in the development of IPF and emphysema, respectively [137-141].

These evolving concepts open new options to better understand the pathogenesis of both IPF and COPD, as far as the involvement of both parenchymal and small airway components are concerned [142,143], and also new perspectives for alternative treatment options, including drugs specifically addressing some of the mechanisms described in this review. The high relevance of the type of cell precursor involved in the two diseases is emphasised, since future efforts should be focused on their pharmacological protection or specific replacement [144-149].

\section{Acknowledgements}

MC was supported by the European Union FP7 Health Research Grant number HEALTH-F4-2008-202047

\section{Author details}

${ }^{1}$ Department of Pathology, University of Verona, Italy. ${ }^{2}$ Department of Diseases of the Thorax, Morgagni Hospital, Forlì, Italy. ${ }^{3}$ Pulmonary Division, Verona General Hospital, Italy.

\section{Authors' contributions}

All Authors participated in the design of the review and helped to draft the manuscript. All authors read and approved the final manuscript.

\section{Competing interests}

The authors declare that they have no competing interests.

Received: 8 November 2011 Accepted: 11 January 2012

Published: 11 January 2012

\section{References}

1. Pauwels RA, Buist AS, Calverley PM, Jenkins CR, Hurd SS: GOLD Scientific Committee. Global strategy for the diagnosis, management, and prevention of chronic obstructive pulmonary disease. NHLBI/WHO Global Initiative for Chronic Obstructive Lung Disease (GOLD) Workshop summary. Am J Respir Crit Care Med 2001, 163:1256-1276.

2. Hogg JC, Timens W: The pathology of chronic obstructive pulmonary disease. Annu Rev Pathol 2009, 4:435-459.

3. American Thoracic Society: Idiopathic pulmonary fibrosis: diagnosis and treatment. International consensus statement. American Thoracic Society (ATS), and the European Respiratory Society (ERS). Am J Respir Crit Care Med 2000, 161:646-664

4. Rabe KF, Hurd S, Anzueto A, Barnes PJ, Buist SA, Calverley P, Fukuchi Y, Jenkins C, Rodriguez-Roisin R, van Weel C, Zielinski J: Global Initiative for Chronic Obstructive Lung Disease. Global strategy for the diagnosis, management, and prevention of chronic obstructive pulmonary disease: GOLD executive summary. Am J Respir Crit Care Med 2007, 176:532-555

5. Mannino DM, Buist AS: Global burden of COPD: risk factors, prevalence, and future trends. Lancet 2007, 370:765-773.

6. Baumgartner KB, Samet JM, Stidley CA, Colby TV, Waldron JA: Cigarette smoking: a risk factor for idiopathic pulmonary fibrosis. Am J Respir Crit Care Med 1997, 155:242-248.

7. Rennard SI, Togo S, Holz O: Cigarette smoke inhibits alveolar repair: a mechanism for the development of emphysema. Proc Am Thorac Soc 2006, 3:703-708.

8. Cottin V, Nunes H, Brillet PY, Delaval P, Devouassoux G, Tillie-Leblond I, Israel-Biet D, Court-Fortune I, Valeyre D, Cordier JF: Combined pulmonary fibrosis and emphysema: a distinct underrecognised entity. Eur Respir $J$ 2005, 26:586-593.
9. Cottin V, Le Pavec J, Prévot G, Mal H, Humbert M, Simonneau G, Cordier JF: Pulmonary hypertension in patients with combined pulmonary fibrosis and emphysema syndrome. Eur Respir J 2010, 35:105-111.

10. Koshiol J, Rotunno M, Consonni D, Pesatori AC, De Matteis S, Goldstein AM, Chaturvedi AK, Wacholder S, Landi MT, Lubin JH, Caporaso N: Chronic obstructive pulmonary disease and altered risk of lung cancer in a population-based case-control study. PLoS One 2009, 4:e7380.

11. Hubbard R, Venn A, Lewis S, Britton J: Lung cancer and cryptogenic fibrosing alveolitis. A population-based cohort study. Am J Respir Crit Care Med 2000, 161:5-8.

12. MacNee W, Tuder RM: New paradigms in the pathogenesis of chronic obstructive pulmonary disease I. Proc Am Thorac Soc 2009, 6:527-531.

13. Strieter RM, Mehrad B: New mechanisms of pulmonary fibrosis. Chest 2009, 136:1364-1370

14. Ceylan E, Kocyigit A, Gencer M, Aksoy N, Selek S: Increased DNA damage in patients with chronic obstructive pulmonary disease who had once smoked or been exposed to biomass. Respir Med 2006, 100:1270-1276.

15. Chilosi M, Murer B, Poletti V: Usual Interstitial Pneumonia. In Molecular Pathology of lung diseases, Springer Edited by: Zander S, Popper HH, Jagirdar J, Haque AK, Cagle PT, Barrios R 2008, 607-615.

16. Selman M, Pardo A, Kaminski N: Idiopathic pulmonary fibrosis: aberrant recapitulation of developmental programs? PLoS Med 2008, 5:e62.

17. King TE Jr, Pardo A, Selman M: Idiopathic pulmonary fibrosis. Lancet 2011, 378:1949-1961

18. Pierrou S, Broberg P, O’Donnell RA, Pawłowski K, Virtala R, Lindqvist $E$, Richter A, Wilson SJ, Angco G, Möller S, Bergstrand H, Koopmann W, Wieslander E, Strömstedt PE, Holgate ST, Davies DE, Lund J, Djukanovic R: Expression of genes involved in oxidative stress responses in airway epithelial cells of smokers with chronic obstructive pulmonary disease. Am J Respir Crit Care Med 2007, 175:577-586.

19. Tsuji T, Aoshiba K, Nagai A: Alveolar cell senescence in patients with pulmonary emphysema. Am J Respir Crit Care Med 2006, 174:886-893.

20. Tsuji T, Aoshiba K, Nagai A: Alveolar Cell Senescence Exacerbates Pulmonary Inflammation in Patients with Chronic Obstructive Pulmonary Disease. Respiration 2010, 80:59-70.

21. Ito K, Barnes PJ: COPD as a disease of accelerated lung aging. Chest 2009 135:173-180

22. Karrasch S, Holz O, Jörres RA: Aging and induced senescence as factors in the pathogenesis of lung emphysema. Respir Med 2008, 102:1215-1230.

23. MacNee W: Accelerated lung aging: a novel pathogenic mechanism of chronic obstructive pulmonary disease (COPD). Biochem Soc Trans 2009 37:819-823.

24. Mui TS, Man JM, McElhaney JE, Sandford AJ, Coxson HO, Birmingham CL, Li Y, Man SF, Sin DD: Telomere length and chronic obstructive pulmonary disease: evidence of accelerated aging. J Am Geriatr Soc 2009, 57:2372-2374.

25. Houben JM, Mercken EM, Ketelslegers HB, Bast A, Wouters EF, Hageman GJ, Schols AM: Telomere shortening in chronic obstructive pulmonary disease. Respir Med 2009, 103:230-236.

26. Savale L, Chaouat A, Bastuji-Garin S, Marcos E, Boyer L, Sarni M, Housset B, Weitzenblum E, Matrat M, Le Corvoisier P, Rideau D, Boczkowski J, Duboisandé $J \mathrm{~L}$, Chouaid $\mathrm{C}$, Adnot S: Shortened telomeres in circulating leukocytes of patients with chronic obstructive pulmonary disease. Am J Respir Crit Care Med 2009, 179:566-571.

27. Alder JK, Guo N, Kembou F, Parry EM, Anderson CJ, Gorgy Al, Walsh MF, Sussan T, Biswal S, Mitzner W, Tuder RM, Armanios M: Telomere Length is a Determinant of Emphysema Susceptibility. Am J Respir Crit Care Med 2011

28. Minagawa S, Araya J, Numata T, Nojiri S, Hara H, Yumino Y, Kawaishi M, Odaka M, Morikawa T, Nishimura SL, Nakayama K, Kuwano K: Accelerated epithelial cell senescence in IPF and the inhibitory role of SIRT6 in TGF$\beta$-induced senescence of human bronchial epithelial cells. Am J Physiol Lung Cell Mol Physiol 2011, 300:L391-401.

29. Armanios MY, Chen JJ, Cogan JD, Alder JK, Ingersoll RG, Markin C Lawson WE, Xie M, Vulto I, Phillips JA, Lansdorp PM, Greider CW, Loyd JE: Telomerase mutations in families with idiopathic pulmonary fibrosis. $\mathrm{N}$ Engl J Med 2007, 356:1317-1326.

30. Tsakiri KD, Cronkhite JT, Kuan PJ, Xing C, Raghu G, Weissler JC, Rosenblatt RL, Shay JW, Garcia CK: Adult-onset pulmonary fibrosis caused by mutations in telomerase. Proc Natl Acad Sci USA 2007, 104:7552-7557. 
31. Cronkhite JT, Xing C, Raghu G, Chin KM, Torres F, Rosenblatt RL, Garcia CK Telomere shortening in familial and sporadic pulmonary fibrosis. Am J Respir Crit Care Med 2008, 178:729-737.

32. Antoniou KM, Papadaki HA, Soufla G, Siafakas NM: Short telomeres and treatment of pulmonary fibrosis: implications for early intervention. Am J Respir Crit Care Med 2009, 179:970.

33. Diaz de Leon A, Cronkhite JT, Katzenstein AL, Godwin JD, Raghu G, Glazer CS, Rosenblatt RL, Girod CE, Garrity ER, Xing C, Garcia CK: Telomere lengths, pulmonary fibrosis and telomerase (TERT) mutations. PLoS One 2010, 5:e10680.

34. Alder JK, Cogan JD, Brown AF, Anderson CJ, Lawson WE, Lansdorp PM, Phillips JA, Loyd JE, Chen JJ, Armanios M: Ancestral mutation in telomerase causes defects in repeat addition processivity and manifests as familial pulmonary fibrosis. PLoS Genet 2011, 7:e1001352.

35. Tuder RM, Yun JH, Graham BB: Cigarette smoke triggers code red: p21CIP1/WAF1/SDI1 switches on danger responses in the lung. Am J Respir Cell Mol Biol 2008, 39:1-6.

36. Imokawa S, Sato A, Toyoshima MYoshitomi A, Tamura R, Suda T, Suganuma H, Yagi T, Iwata M, Hayakawa H, Chida H: Dyskeratosis congenita showing usual interstitial pneumonia. Intern Med 1994, 33:226-230.

37. Nussbaumer-Ochsner $Y$, Rabe KF: Systemic manifestations of COPD. Chest 2011, 139(1):165-173.

38. Wong LS, van der Harst P, de Boer RA, Huzen J, van Gilst WH, van Veldhuisen DJ: Aging, telomeres and heart failure. Heart Fail Rev 2010, 15:479-486.

39. Simon NM, Smoller JW, McNamara KL, Maser RS, Zalta AK, Pollack MH, Nierenberg AA, Fava M, Wong KK: Telomere shortening and mood disorders: preliminary support for a chronic stress model of accelerated aging. Biol Psychiatry 2006, 60:432-435.

40. Alder JK, Guo N, Kembou F, Parry EM, Anderson CJ, Gorgy Al, Walsh MF, Sussan T, Biswal S, Mitzner W, Tuder RM, Armanios M: Telomere Length is a Determinant of Emphysema Susceptibility. Am J Respir Crit Care Med 2011.

41. Armanios M: Syndromes of telomere shortening. Annu Rev Genomics Hum Genet 2009, 10:45-61.

42. Calado RT, Young NS: Telomere diseases. N Engl J Med 2009, 361:2353-2365.

43. Vulliamy T, Beswick R, Kirwan M, Marrone A, Digweed M, Walne A, Dokal I: Mutations in the telomerase component NHP2 cause the premature ageing syndrome dyskeratosis congenita. Proc Natl Acad Sci USA 2008, 105:8073-8078.

44. Kirwan M, Dokal I: Dyskeratosis congenita, stem cells and telomeres. Biochim Biophys Acta 2009, 1792:371-379.

45. Ly H: Genetic and environmental factors influencing human diseases with telomere dysfunction. Int J Clin Exp Med 2009, 2:114-130.

46. Flores I, Blasco MA: The role of telomeres and telomerase in stem cell aging. FEBS Lett 2010, 584:3826-3830.

47. Hao LY, Armanios M, Strong MA, Karim B, Feldser DM, Huso D, Greider CW: Short telomeres, even in the presence of telomerase, limit tissue renewal capacity. Cell 2005, 123:1121-1131.

48. Borie $\mathrm{R}$, Crestani B, Bichat $\mathrm{H}$ : Prevalence of telomere shortening in familial and sporadic pulmonary fibrosis is increased in men. Am J Respir Crit Care Med 2009, 179:1073

49. Safa WF, Lestringant GG, Frossard PM: X-linked dyskeratosis congenita: restrictive pulmonary disease and a novel mutation. Thorax 2001, 56:891-894.

50. Utz JP, Ryu JH, Myers JL, Michels W: Usual interstitial pneumonia complicating dyskeratosis congenita. Mayo Clin Proc 2005, 80:817-821.

51. Lawson WE, Loyd JE, Degryse AL: Genetics in pulmonary fibrosis-familial cases provide clues to the pathogenesis of idiopathic pulmonary fibrosis. Am J Med Sci 2011, 341:439-443.

52. Nogee LM, Dunbar AE, Wert SE, Askin F, Hamvas A, Whitsett JA: A mutation in the surfactant protein $C$ gene associated with familial interstitial lung disease. N Engl J Med 2001, 344:573-579.

53. Whitsett JA: Genetic basis of familial interstitial lung disease: misfolding or function of surfactant protein C? Am J Respir Crit Care Med 2002, 165:1201-1202.

54. Lawson WE, Grant SW, Ambrosini V, Womble KE, Dawson EP, Lane KB, Markin C, Renzoni E, Lympany P, Thomas AQ, Roldan J, Scott TA, Blackwell TS, Phillips JA, Loyd JE, du Bois RM: Genetic mutations in surfactant protein $\mathrm{C}$ are a rare cause of sporadic cases of IPF. Thorax 2004, 59:977-980.

55. Lawson WE, Crossno PF, Polosukhin W, Roldan J, Cheng DS, Lane KB, Blackwell TR, Xu C, Markin C, Ware LB, Miller GG, Loyd JE, Blackwell TS: Endoplasmic reticulum stress in alveolar epithelial cells is prominent in IPF: association with altered surfactant protein processing and herpesvirus infection. Am J Physiol Lung Cell Mol Physiol 2008, 294: L1119-L1126.

56. Chilosi M, Doglioni C, Murer B, Poletti V: Epithelial stem cell exhaustion in the pathogenesis of idiopathic pulmonary fibrosis. Sarcoidosis Vasc Diffuse Lung Dis 2010, 27:7-18.

57. Korfei M, Ruppert C, Mahavadi P, Henneke I, Markart P, Koch M, Lang G, Fink L, Bohle RM, Seeger W, Weaver TE, Guenther A: Epithelial endoplasmic reticulum stress and apoptosis in sporadic idiopathic pulmonary fibrosis. Am J Respir Crit Care Med 2008, 178:838-846.

58. Lawson WE, Cheng DS, Degryse AL, Tanjore H, Polosukhin W, Xu XC, Newcomb DC, Jones BR, Roldan J, Lane KB, Morrisey EE, Beers MF, Yull FE, Blackwell TS: Endoplasmic reticulum stress enhances fibrotic remodeling in the lungs. Proc Natl Acad Sci USA 2011, 108:10562-10567.

59. Sisson TH, Mendez M, Choi K, Subbotina N, Courey A, Cunningham A, Dave A, Engelhardt JF, Liu X, White ES, Thannickal VJ, Moore BB, Christensen PJ, Simon RH: Targeted injury of type II alveolar epithelial cells induces pulmonary fibrosis. Am J Respir Crit Care Med 2010, 181:254-263.

60. Babizhayev MA, Savel'yeva EL, Moskvina SN, Yegorov YE: Telomere Length is a Biomarker of Cumulative Oxidative Stress, Biologic Age, and an Independent Predictor of Survival and Therapeutic Treatment Requirement Associated With Smoking Behavior. Am J Ther 2010.

61. Müller KC, Welker L, Paasch K, Feindt B, Erpenbeck VJ, Hohlfeld JM, Krug N, Nakashima M, Branscheid D, Magnussen H, Jörres RA, Holz O: Lung fibroblasts from patients with emphysema show markers of senescence in vitro. Respir Res 2006, 7:32.

62. Kasahara Y, Tuder RM, Taraseviciene-Stewart L, Le Cras TD, Abman S, Hirth PK, Waltenberger J, Voelkel NF: Inhibition of VEGF receptors causes lung cell apoptosis and emphysema. J Clin Invest 2000, 106:1311-1319.

63. Kasahara Y, Tuder RM, Cool CD, Lynch DA, Flores SC, Voelkel NF: Endothelial cell death and decreased expression of vascular endothelial growth factor and vascular endothelial growth factor receptor 2 in emphysema. Am J Respir Crit Care Med 2001, 163:737-744.

64. Horowitz JC, Martinez FJ, Thannickal VJ: Mesenchymal cell fate and phenotypes in the pathogenesis of emphysema. COPD 2009, 6:201-210.

65. Togo S, Holz O, Liu X, Sugiura H, Kamio K, Wang X, Kawasaki S, Ahn Y, Fredriksson K, Skold CM, Mueller KC, Branscheid D, Welker L, Watz H, Magnussen H, Rennard SI: Lung fibroblast repair functions in patients with chronic obstructive pulmonary disease are altered by multiple mechanisms. Am J Respir Crit Care Med 2008, 178:248-260.

66. Noordhoek JA, Postma DS, Chong LL, Vos JT, Kauffman HF, Timens W, van Straaten JF: Different proliferative capacity of lung fibroblasts obtained from control subjects and patients with emphysema. Exp Lung Res 2003, 29:291-302.

67. Paschalaki K, Starke RD, Mercado N, Haskard DO, Barnes PJ, Randi AM: 59 Endothelial colony forming cells (ECFC) are senescent and dysfunctional in COPD due to reduced sirtuin-1 levels. Heart 2011, 97:e7.

68. Giordano RJ, Lahdenranta J, Zhen L, Chukwueke U, Petrache I, Langley RR, Fidler IJ, Pasqualini R, Tuder RM, Arap W: Targeted induction of lung endothelial cell apoptosis causes emphysemalike changes in the mouse. J Biol Chem 2008, 283:29447-29460.

69. Codd V, Mangino M, van der Harst P, Braund PS, Kaiser M, Beveridge AJ, Rafelt S, Moore J, Nelson C, Soranzo N, Zhai G, Valdes AM, Blackburn H, Mateo Leach I, de Boer RA, Kimura M, Aviv A, Wellcome Trust Case Control Consortium, Goodall AH, Ouwehand W, van Veldhuisen DJ, van Gilst WH, Navis G, Burton PR, Tobin MD, Hall AS, Thompson JR, Spector T, Samani NJ: Common variants near TERC are associated with mean telomere length. Nat Genet 2010, 42:197-199.

70. Seibold MA, Wise AL, Speer MC, Steele MP, Brown KK, Loyd JE, Fingerlin TE, Zhang W, Gudmundsson G, Groshong SD, Evans CM, Garantziotis S, Adler KB, Dickey BF, du Bois RM, Yang IV, Herron A, Kervitsky D, Talbert JL, Markin C, Park J, Crews AL, Slifer SH, Auerbach S, Roy MG, Lin J, Hennessy CE, Schwarz MI, Schwartz DA: A common MUC5B promoter polymorphism and pulmonary fibrosis. N Engl J Med 2011, 364:1503-1512. 
71. Hersh CP, Silverman EK, Gascon J, Bhattacharya S, Klanderman BJ, Litonjua AA, Lefebvre V, Sparrow D, Reilly JJ, Anderson WH, Lomas DA, Mariani TJ: SOX5 Is a Candidate Gene for Chronic Obstructive Pulmonary Disease Susceptibility and Is Necessary for Lung Development. Am J Respir Crit Care Med 2011, 183:1482-1489.

72. Whitsett JA, Kalinichenko W: Notch and basal cells take center stage during airway epithelial regeneration. Cell Stem Cell 2011, 8:597-598.

73. Ling L, Nurcombe V, Cool SM: Wnt signaling controls the fate of mesenchymal stem cells. Gene 2009, 433:1-7.

74. Xu K, Nieuwenhuis E, Cohen BL, Wang W, Canty AJ, Danska JS, Coultas L, Rossant J, Wu MY, Piscione TD, Nagy A, Gossler A, Hicks GG, Hui CC, Henkelman RM, Yu LX, Sled JG, Gridley T, Egan SE: Lunatic Fringemediated Notch signaling is required for lung alveogenesis. Am J Physiol Lung Cell Mol Physiol 2010, 298:L45-56.

75. Liu J, Sato C, Cerletti M, Wagers A: Notch signaling in the regulation of stem cell self-renewal and differentiation. Curr Top Dev Biol 2010, 92:367-409.

76. Rock JR, Gao X, Xue Y, Randell SH, Kong YY, Hogan BL: Notch-dependent differentiation of adult airway basal stem cells. Cell Stem Cell 2011, 8:639-648.

77. Nusse R: Wnt signaling and stem cell control. Cell Res 2008, 18:523-527

78. Goss AM, Morrisey EE: Wnt signaling and specification of the respiratory endoderm. Cell Cycle 2010, 9:10-11.

79. Leslie KO, Idiopathic pulmonary fibrosis may be a disease of recurrent tractional injury to the periphery of the aging lung: a unifying hypothesis regarding etiology and pathogenesis. Arch Pathol Lab Med 2011, 135:1-10.

80. Chilosi M, Poletti V, Zamò A, Lestani M, Montagna L, Piccoli P, Pedron S, Bertaso M, Scarpa A, Murer B, Cancellieri A, Maestro R, Semenzato G, Doglioni C: Aberrant Wnt/beta-catenin pathway activation in idiopathic pulmonary fibrosis. Am J Pathol 2003, 162:1495-1502.

81. Königshoff M, Balsara N, Pfaff EM, Kramer M, Chrobak I, Seeger W, Eickelberg O: Functional Wnt signaling is increased in idiopathic pulmonary fibrosis. PLoS One 2008, 3:e2142

82. Königshoff M, Kramer M, Balsara N, Wilhelm J, Amarie OV, Jahn A, Rose F, Fink L, Seeger W, Schaefer L, Günther A, Eickelberg O: WNT1-inducible signalling protein-1 mediates pulmonary fibrosis in mice and is upregulated in humans with idiopathic pulmonary fibrosis. J Clin Invest 2009, 119:772-787.

83. Kim TH, Kim SH, Seo JY, Chung H, Kwak HJ, Lee SK, Yoon HJ, Shin DH, Park SS, Sohn JW: Blockade of the Wnt/ $\beta$-catenin pathway attenuates bleomycin-induced pulmonary fibrosis. Tohoku J Exp Med 2011, 223:45-54.

84. Vuga LJ, Ben-Yehudah A, Kovkarova-Naumovski E, Oriss T, Gibson KF, Feghali-Bostwick C, Kaminski N: WNT5A is a regulator of fibroblast proliferation and resistance to apoptosis. Am J Respir Cell Mol Biol 2009, 41:583-589.

85. Salazar KD, Lankford SM, Brody AR: Mesenchymal stem cells produce Wnt isoforms and TGF-beta1 that mediate proliferation and procollagen expression by lung fibroblasts. Am J Physiol Lung Cell Mol Physiol 2009, 297:L1002-11.

86. Liu T, Hu B, Chung MJ, Ullenbruch M, Jin H, Phan SH: Telomerase regulation of myofibroblast differentiation. Am J Respir Cell Mol Biol 2006, 34:625-633.

87. Guseh JS, Bores SA, Stanger BZ, Zhou Q, Anderson WJ, Melton DA, Rajagopal J: Notch signaling promotes airway mucous metaplasia and inhibits alveolar development. Development 2009, 136:1751-1759.

88. Buckley S, Shi W, Carraro G, Sedrakyan S, Da Sacco S, Driscoll BA, Perin L, de Filippo RE, Warburton D: The Milieu of Damaged AEC2 Stimulates Alveolar Wound Repair by Endogenous and Exogenous Progenitors. Am J Respir Cell Mol Biol 2011.

89. Coppé JP, Desprez PY, Krtolica A, Campisi J: The senescence-associated secretory phenotype: the dark side of tumor suppression. Annu Rev Pathol 2010, 5:99-118.

90. Meshorer E, Gruenbaum Y: Gone with the Wnt/Notch: stem cells in laminopathies, progeria, and aging. J Cell Biol 2008, 181:9-13.

91. Scaffidi P, Misteli T: Lamin A-dependent misregulation of adult stem cells associated with accelerated ageing. Nat Cell Biol 2008, 10:452-459.

92. Espada J, Varela I, Flores I, Ugalde AP, Cadiñanos J, Pendás AM, Stewart CL, Tryggvason K, Blasco MA, Freije JM, López-Otín C: Nuclear envelope defects cause stem cell dysfunction in premature-aging mice. J Cell Biol 2008, 181:27-35.
93. Liu H, Fergusson MM, Castilho RM, Liu J, Cao L, Chen J, Malide D, Rovira II, Schimel D, Kuo CJ, Gutkind JS, Hwang PM, Finkel T: Augmented Wnt signaling in a mammalian model of accelerated aging. Science 2007, 317:803-806.

94. Davalos AR, Coppe JP, Campisi J, Desprez PY: Senescent cells as a source of inflammatory factors for tumor progression. Cancer Metastasis Rev 2010, 29:273-283.

95. Laberge RM, Awad P, Campisi J, Desprez PY: Epithelial-Mesenchymal Transition Induced by Senescent Fibroblasts. Cancer Microenviron 2011.

96. Chilosi M, Poletti V, Murer B, Lestani M, Cancellieri A, Montagna L, Piccoli P, Cangi G, Semenzato G, Doglioni C: Abnormal re-epithelialization and lung remodeling in idiopathic pulmonary fibrosis: the role of deltaN-p63. Lab Invest 2002, 82:1335-1345.

97. Chilosi M, Zamò A, Doglioni C, Reghellin D, Lestani M, Montagna L, Pedron S, Ennas MG, Cancellieri A, Murer B, Poletti V: Migratory marker expression in fibroblast foci of idiopathic pulmonary fibrosis. Respir Res 2006, 7:95.

98. Rock JR, Onaitis MW, Rawlins EL, Lu Y, Clark CP, Xue Y, Randell SH, Hogan BL: Basal cells as stem cells of the mouse trachea and human airway epithelium. Proc Natl Acad Sci USA 2009, 106:12771-12775.

99. Senoo M, Pinto F, Crum CP, McKeon F: p63 Is essential for the proliferative potential of stem cells in stratified epithelia. Cell 2007, 129:523-536.

100. Plantier L, Crestani B, Wert SE, Dehoux M, Zweytick B, Guenther A, Whitsett JA: Ectopic respiratory epithelial cell differentiation in bronchiolised distal airspaces in idiopathic pulmonary fibrosis. Thorax 2011

101. Kirkham S, Kolsum U, Rousseau K, Singh D, Vestbo J, Thornton DJ: MUC5B is the major mucin in the gel phase of sputum in chronic obstructive pulmonary disease. Am J Respir Crit Care Med 2008, 178:1033-1039.

102. Tilley AE, Harvey BG, Heguy A, Hackett NR, Wang R, O'Connor TP, Crystal RG: Down-regulation of the notch pathway in human airway epithelium in association with smoking and chronic obstructive pulmonary disease. Am J Respir Crit Care Med 2009, 179:457-466.

103. Wang R, Ahmed J, Wang G, Hassan I, Strulovici-Barel Y, Hackett NR, Crystal RG: Down-regulation of the canonical Wnt $\beta$-catenin pathway in the airway epithelium of healthy smokers and smokers with COPD. PLOS One 2011, 6:e14793.

104. Kneidinger N, Yildirim AÖ, Callegari J, Takenaka S, Stein MM, Dumitrascu R, Bohla A, Bracke KR, Morty RE, Brusselle GG, Schermuly RT, Eickelberg O, Königshoff M: Activation of the WNT/B-catenin pathway attenuates experimental emphysema. Am J Respir Crit Care Med 2011, 183:723-733.

105. Jansen JH, Eijken $M$, Jahr $H$, Chiba $H$, Verhaar JA, van Leeuwen JP, Weinans $\mathrm{H}$ : Stretch-induced inhibition of Wnt/beta-catenin signaling in mineralizing osteoblasts. J Orthop Res 2010, 28:390-396.

106. Sen B, Styner M, Xie Z, Case N, Rubin CT, Rubin J: Mechanical loading regulates NFATC1 and beta-catenin signaling through a GSK3beta control node. J Biol Chem 2009, 284:34607-17.

107. Arnsdorf EJ, Tummala P, Jacobs CR: Non-canonical Wnt signaling and Ncadherin related beta-catenin signaling play a role in mechanically induced osteogenic cell fate. PLOS One 2009, 4(4):e5388.

108. Kononov S, Brewer K, Sakai H, Cavalcante FS, Sabayanagam CR, Ingenito EP, Suki B: Roles of mechanical forces and collagen failure in the development of elastase-induced emphysema. Am J Respir Crit Care Med 2001, 164:1920-1926.

109. Cosio MG, Saetta M, Agusti A: Immunologic aspects of chronic obstructive pulmonary disease. N Engl J Med 2009, 360:2445-2454.

110. Barceló B, Pons J, Ferrer JM, Sauleda J, Fuster A, Agustí AGN: Phenotypic characterisation of T-lymphocytes in COPD: abnormal CD4+CD25+ regulatory T-lymphocyte response to tobacco smoking. Eur Respir J 2008, 31:555-562.

111. Saetta M: Airway inflammation in chronic obstructive pulmonary disease. Am J Respir Crit Care Med 1999, 160:S17-20.

112. Baraldo S, Saetta M: To reg or not to reg: that is the question in COPD. Eur Respir J 2008, 31:486-488.

113. Motz GT, Eppert BL, Wesselkamper SC, Flury JL, Borchers MT: Chronic cigarette smoke exposure generates pathogenic $T$ cells capable of driving COPD-like disease in Rag2-/- mice. Am J Respir Crit Care Med 2010, 181:1223-1233

114. Taraseviciene-Stewart L, Douglas IS, Nana-Sinkam PS, Lee JD, Tuder RM, Nicolls MR, Voelkel NF: Is alveolar destruction and emphysema in chronic 
obstructive pulmonary disease an immune disease? Proc Am Thorac Soc 2006, 3:687-690.

115. Zhou F, Onizawa S, Nagai A, Aoshiba K: Epithelial cell senescence impairs repair process and exacerbates inflammation after airway injury. Respir Res 2011, 12:78.

116. Aggarwal S, Pittenger MF: Human mesenchymal stem cells modulate allogeneic immune cell responses. Blood 2005, 105:1815-1822.

117. Krampera M, Pasini A, Pizzolo G, Cosmi L, Romagnani S, Annunziato F: Regenerative and immunomodulatory potential of mesenchymal stem cells. Curr Opin Pharmacol 2006, 6:435-441.

118. Le Blanc K, Ringdén O: Immunomodulation by mesenchymal stem cells and clinical experience. J Intern Med 2007, 262:509-525.

119. Uccelli A, Moretta L, Pistoia V: Mesenchymal stem cells in health and disease. Nat Rev Immunol 2008.

120. Krampera M, Sartoris S, Liotta F, Pasini A, Angeli R, Cosmi L, Andreini A, Mosna F, Bonetti B, Rebellato E, Testi MG, Frosali F, Pizzolo G, Tridente G, Maggi E, Romagnani $S$, Annunziato F: Immune regulation by mesenchymal stem cells derived from adult spleen and thymus. Stem Cells Dev 2007, 16:797-810.

121. Keyser KA, Beagles KE, Kiem HP: Comparison of mesenchymal stem cells from different tissues to suppress T-cell activation. Cell Transplant 2007, 16:555-562.

122. Parker SM, Goriwiec MR, Borthwick LA, Johnson G, Ward C, Lordan JL, Corris PA, Saretzki GC, Fisher AJ: Airway epithelial cell senescence in the lung allograft. Am J Transplant 2008, 8:1544-1549.

123. Ghanei M, Tazelaar HD, Chilosi M, Harandi AA, Peyman M, Akbari HM, Shamsaei $\mathrm{H}$, Bahadori M, Aslani J, Mohammadi A: An international collaborative pathologic study of surgical lung biopsies from mustard gas-exposed patients. Respir Med 2008, 102:825-830

124. King MS, Eisenberg R, Newman JH, Tolle JJ, Harrell FE Jr, Nian H, Ninan M, Lambright ES, Sheller JR, Johnson JE, Miller RF: Constrictive bronchiolitis in soldiers returning from Iraq and Afghanistan. N Engl J Med 2011, 365:222-230.

125. Maldonado F, Pittelkow MR, Ryu JH: Constrictive bronchiolitis associated with paraneoplastic autoimmune multi-organ syndrome. Respirology 2009, 14:129-133.

126. Devouassoux G, Cottin V, Lioté H, Marchand E, Frachon I, Schuller A, BéjuiThivolet F, Cordier JF: Characterisation of severe obliterative bronchiolitis in rheumatoid arthritis. Eur Respir J 2009, 33:1053-1061.

127. Amsellem V, Gary-Bobo G, Marcos E, Maitre B, Chaar V, Validire P, Stern JB, Noureddine H, Sapin E, Rideau D, Hue S, Le Corvoisier P, Le Gouvello S, Dubois-Randé JL, Boczkowski J, Adnot S: Telomere Dysfunction Causes Sustained Inflammation in Chronic Obstructive Pulmonary Disease. Am J Respir Crit Care Med 2011.

128. Liu G, Friggeri A, Yang Y, Milosevic J, Ding Q, Thannickal VJ, Kaminski N, Abraham E: miR-21 mediates fibrogenic activation of pulmonary fibroblasts and lung fibrosis. J Exp Med 2010, 207:1589-1597.

129. Pandit KV, Milosevic J, Kaminski N: MicroRNAs in idiopathic pulmonary fibrosis. Transl Res 2011, 157:191-199.

130. Castaldi PJ, Cho MH, Cohn M, Langerman F, Moran S, Tarragona N, Moukhachen H, Venugopal R, Hasimja D, Kao E, Wallace B, Hersh CP, Bagade S, Bertram L, Silverman EK, Trikalinos TA: The COPD genetic association compendium: a comprehensive online database of COPD genetic associations. Hum Mol Genet 2010, 19:526-534.

131. Sørheim IC, DeMeo DL, Washko G, Litonjua A, Sparrow D, Bowler R, Bakke P, Pillai SG, Coxson HO, Lomas DA, Silverman EK, Hersh CP: International COPD Genetics Network Investigators. Polymorphisms in the superoxide dismutase-3 gene are associated with emphysema in COPD COPD 2010, 7:262-268.

132. Hersh CP, Silverman EK, Gascon J, Bhattacharya S, Klanderman BJ, Litonjua AA, Lefebvre V, Sparrow D, Reilly JJ, Anderson WH, Lomas DA, Mariani TJ: SOX5 is a candidate gene for chronic obstructive pulmonary disease susceptibility and is necessary for lung development. Am J Respir Crit Care Med 2011, 183:1482-1489.

133. Li LJ, Gao LB, Lv ML, Dong W, Su XW, Liang WB, Zhang L: Association between SNPs in pre-miRNA and risk of chronic obstructive pulmonary disease. Clin Biochem 2011, 44:813-816.

134. Willis BC, Liebler JM, Luby-Phelps K, Nicholson AG, Crandall ED, du Bois RM, Borok Z: Induction of epithelial-mesenchymal transition in alveolar epithelial cells by transforming growth factor-beta1: potential role in idiopathic pulmonary fibrosis. Am J Pathol 2005, 166:1321-1332.
135. Morty RE, Königshoff M, Eickelberg O, Transforming growth factor-beta signaling across ages: from distorted lung development to chronic obstructive pulmonary disease. Proc Am Thorac Soc 2009, 6:607-613.

136. Baarsma HA, Spanjer Al, Haitsma G, Engelbertink LH, Meurs H, Jonker MR, Timens W, Postma DS, Kerstjens HA, Gosens R: Activation of WNT/ $\beta$ catenin signaling in pulmonary fibroblasts by TGF- $\beta_{1}$ is increased in chronic obstructive pulmonary disease. PLoS One 2011, 6:e25450.

137. Volonte D, Kahkonen B, Shapiro S, Di Y, Galbiati F: Caveolin-1 expression is required for the development of pulmonary emphysema through activation of the ATM-p53-p21 pathway. J Biol Chem 2009, 284:5462-5466.

138. Le Saux O, Teeters K, Miyasato S, Choi J, Nakamatsu G, Richardson JA, Starcher B, Davis EC, Tam EK, Jourdan-Le Saux C: The role of caveolin-1 in pulmonary matrix remodeling and mechanical properties. Am J Physiol Lung Cell Mol Physiol 2008, 295:L1007-L1017.

139. Dasari A, Bartholomew JN, Volonte D, Galbiati F: Oxidative stress induces premature senescence by stimulating caveolin-1 gene transcription through p38 mitogen-activated protein kinase/Sp1-mediated activation of two GC-rich promoter elements. Cancer Res 2006, 66:10805-10814.

140. Galbiati F, Volonte D, Brown AM, Weinstein DE, Ben-Ze'ev A, Pestell RG, Lisanti MP: Caveolin-1 expression inhibits Wnt/beta-catenin/Lef-1 signaling by recruiting beta-catenin to caveolae membrane domains. $\rfloor$ Biol Chem 2000, 275:23368-23377.

141. Wang XM, Zhang Y, Kim HP, Zhou Z, Feghali-Bostwick CA, Liu F, Ifedigbo E, Xu X, Oury TD, Kaminski N, Choi AM: Caveolin-1: a critical regulator of lung fibrosis in idiopathic pulmonary fibrosis. J Exp Med 2006, 203:2895-2906

142. Chilosi M, Poletti V, Murer B, Semenzato G, Doglioni C: Bronchiolar epithelium in idiopathic pulmonary fibrosis/usual interstitial pneumonia In: Idiopathic pulmonary fibrosis. In Lung Biology in health and disease. Edited by: Lynch JPI. Marcel Dekker New York; 2004:631-664.

143. Mitzner W: Emphysema - a disease of small airways or lung parenchyma? N Engl J Med 2011, 365:1637-1639.

144. Ishizawa K, Kubo H, Yamada M, Kobayashi S, Numasaki M, Ueda S, Suzuki T, Sasaki H: Bone marrow-derived cells contribute to lung regeneration after elastase-induced pulmonary emphysema. FEBS Lett 2004, 556:249-252.

145. Huh JW, Kim SY, Lee JH, Lee JS, Ta QV, Kim MJ, Oh YM, Lee YS, Lee SD: Bone marrow cells repair cigarette smoke-induced emphysema in rats. Am J Physiol Lung Cell Mol Physiol 2011

146. Müller I, Lymperi S, Dazzi F: Mesenchymal stem cell therapy for degenerative inflammatory disorders. Curr Opin Organ Transplant 2008, 13:639-644.

147. Aguilar S, Scotton CJ, McNulty K, Nye E, Stamp G, Laurent G, Bonnet D, Janes SM: Bone marrow stem cells expressing keratinocyte growth factor via an inducible lentivirus protects against bleomycin-induced pulmonary fibrosis. PLoS One 2009, 4:e8013.

148. Brooke G, Cook M, Blair C, Han R, Heazlewood C, Jones B, Kambouris M, Kollar K, McTaggart S, Pelekanos R, Rice A, Rossetti T, Atkinson K: Therapeutic applications of mesenchymal stromal cells. Semin Cell Dev Biol 2007, 18:846-858.

149. Tzouvelekis A, Antoniadis A, Bouros D: Stem cell therapy in pulmonary fibrosis. Curr Opin Pulm Med 2011.

doi:10.1186/1465-9921-13-3

Cite this article as: Chilosi et al:: The pathogenesis of COPD and IPF: Distinct horns of the same devil? Respiratory Research 2012 13:3. 